\title{
EFFECT OF CYNARA SCOLYMUS L. (ARTICHOKE) EXTRACT ON LIPID PROFILE OF HYPERLIPIDEMIC MALE RATS
}

\author{
${ }^{1 *}$ Ghada, Z A Soliman, PhD; ${ }^{2 *}$ Tamer M M Saad, PhD \\ ${ }^{1}$ National Nutrition Institute. Cairo; ${ }^{2}$ Medical Research Department, Nuclear \\ Materials Authority, Cairo.
}

\begin{abstract}
:
Introduction: Cynara scolymus L. (Artichoke) grows in Egypt and other countries. It is used as foods and has medicinal properties. Artichoke extracts have been shown to produce various pharmacological effects, such as the inhibition of cholesterol biosynthesis and low density lipoprotein (LDL) oxidation.
\end{abstract}

Purpose: To study the effect of Cynara scolymus $L$. and its extract on lipid profile of hyperlipidemic male rats.

Study Design: Eighty male albino rats, Sprague-Dawley strain, weighing $(204.0 \pm 10)$ were housed individually in wire-mesh cages. Induction of hyperlipidemia was carried out on all rats except negative control group by addition of cholesterol to the basal diet $(2 \%)+0.25$ bile salts (taurocholic) for 4 weeks. After that the rats were divided into 8 groups (10 rats each), the first $\left(1^{\text {st }}\right)$ and $2^{\text {nd }}$ groups was negative (normal) and positive control groups (hyperlipidemic), groups from G 3: G8, they were fed on basal diet supplemented with 2 level of extract ( $4 \& 8 \%$ ) of either heads, heads, or leaves extract. At the end of the experimental period (6 weeks treatment) rats were fasted over night before sacrificing, blood was collected, centrifuged; serum or plasma was stored at $-20{ }^{\circ} \mathrm{C}$ until analysis. Lipid profile and triacylglycerol were measured.

Results and Discussion: Artichoke extracts (plant, head, and leaves) significantly reduced cholesterol, low density lipoprotein cholesterol (LDL-C), very low density lipoprotein cholesterol (VLDL-C) and triacylglycerol. No change was observed with high density lipoprotein cholesterol (HDL-C). Heads extract being more powerful. This effect may be due to its content of mono- and di-caffeoylquinic acids, flavonoids and other contents or through inhibition of LDL oxidation.

Conclusion: artichoke extract seems to be positively modulate hypercholesterolemia and can provide a protection from cardiovascular diseases.

Keywords: Cynara scolymus L. (artichoke), Atherosclerosis; Antioxidant, Lipid profile.

\section{Introduction:}

The use of plants for treating various ailments dates back several centuries. Usually, plants (herbal) medicine has relied on tradition that may or may not be supported by empirical data. The belief that natural medicines are much safer than synthetic drugs has gained popularity in recent years and led to tremendous growth of phytopharmaceutical usage (Bhattaram et al., 2002).

Atherosclerosis is a complex multicellular process, resulting in an unstable atherosclerotic plaque that ultimately bursts, causing myocardial infarction. Botanical dietary supplements (herbs) can ameliorate this process and prevent cardiovascular disease at many steps in the process. Many herbs have antioxidant activity and can reduce low density lipoprotein oxidation. Some phytosterols found in botanicals can inhibit cholesterol absorption (Heber 2001). Hypercholesterolaemia is directly associated with an increased risk of coronary heart disease (CHD) (Holme 1990). Standard drug therapy includes bile 
acid sequestrants, nicotinic acid, fibric acids and HMG-CoA reductase inhibitors (statins) [Expert Panel, 2002]. None of the pharmacological options is free of adverse events and some have been associated with potential carcinogenicity (Expert Panel, 2002). A harmless yet effective treatment option would therefore be of considerable interest. Artichoke leaf extract (ALE) has been suggested as such an option. Effective non-pharmacological treatment consists largely of dietary interventions and increased physical activity and is considered the treatment of choice for primary and secondary prevention of CHD (Pyörälä et al., 1994 a \& b). A favorable effect on serum lipids may be achieved with herbal medicinal products, if they are administered at sufficient high dosages and sufficient long term use. Their efficacy is not so strong than that documented for chemically defined products, however their tolerability is superior (Wegener, 2002). A harmless yet effective treatment option would therefore be of considerable interest. Artichoke leaf extract (ALE) has been suggested as such an option.

Cynara scolymus L. (artichoke) is an important crop of ancient Greece, grows in Egypt, Mediterranean area and other countries. It has been known by the ancient Egyptians, Its green leaves and head are used as foods due to their high nutritive value. Artichoke (Cynara scolymus L.) is one of the world's oldest medicinal plants. It has medical properties. It is used in traditional folk medicine. It is a good source of natural antioxidants such as vitamin $\mathrm{C}$, hydroxycinnamic acids, and flavones (Jimenez et al., 2003). Artichoke and its byproduct contain many compounds as caffeoylquinic acid derivatives and flavonoid. Caffeic acid derivaties are the main phenolic compounds in artichoke heads with a wide range of caffeoylquinic acid derivatives. Apigenin-7-rutinoside and narirutin were found to be unique to artichoke heads (Wang et al., 2003). Cervellati et al., 2002 and Taylor 2002 found that cynarin are used to mobilize fatty stores in the liver and detoxify it.

\section{Content of artichoke:}

From the leaves of Cynara scolymus the following substances where isolated: apigenin, luteolin, luteolin-4'- glucoside, cynaroside, scolimoside, cosmoside, quercetin, rutin, chloro-genic acid, caffeic acid, isochlorogenic acid, luteolin-7-gentiobioside, along with the more uncommon scopoletin, hesperitin, hesperidoside, esculetin-6-O-betaglucoside, maritimein, sesquiterpenes (cynaropicrin, aguerin B, and grosheimin), sesquiterpene glycosides (cynara-scolosides A, B, and C) (Shimoda et al., 2003, Schütz 2006). The anthocyanin of artichoke heads was cyanidin 3, 5-diglucoside, cyanidin 3glucoside, cyanidin 3, 5malonyldiglucoside, cyanidin 3-(3"malonyl) glucoside, and cyanidin 3-(6"malonyl) glucoside which represent the major anthocyanin, two peonidin derivatives and one delphinidin derivative. Total anthocyanin content ranged from 8.4 to $1,705.4 \mathrm{mg} / \mathrm{kg}$ dry mass (Shimoda $\boldsymbol{e t}$ al., 2003, Schütz 2006). Cynarine (1.5-dicaffeoyl-D-quinic acid) is the principal active component of artichoke. The flavonoid luteolin has a role in the inhibition of cholesterol synthesis (Gebhardt 1997).

AIM OF THE WORK: To study the effect of Cynara scolymus L. (balady artichoke) and its extract on lipid profile of hyperlipidemic male rats.

\section{Materials and Methods:}

Preparation of artichoke extract (whole plant, head, and leaves (Wang et al., 2003; and Wagner et al., 1984): a known weight of artichoke was air dried at the room temperature and grinded using a blinder into fine powder. The powdered plant material was macerated in $70 \%$ methanol. Successive addition of aqueous methanol to plant material was carried out till complete exhaustion of the plant. The aqueous methanolic extract was concentrated under reduced pressure using rotatory evaporator till dryness and then weighed. The same was done on the leaves and heads.

\section{Experimental design:}

Eighty male albino rats, SpragueDawley strain, weighing $(204.0 \pm 10 \mathrm{~g})$ were housed individually in wire-mesh cages. All rats were initially fed basal 
(control) diet for 10 days before starting the experiment (adaptation period). The control diet was prepared according to

National Research Council (NRC) Committee on Animal Nutrition, (1978) and Reeves et al., 1993. The water and diets were given ad libitum. Induction of hyperlipidemia was carried out on all rats except negative control group by addition of cholesterol $(2 \%)+0.25 \%$ bile salts to the basal diet for 4 weeks. After that the rats (80) were divided into 8 groups (10 rats each), the first $\left(1^{\text {st }}, \mathrm{G} 1\right)$ second $\left(2^{\text {nd }}, G\right.$ 2) groups was negative (normal) and positive control groups (hyperlipidemic), the third $\left(3^{\text {rd }}, \mathrm{G} 3\right)$ and fourth $\left(4^{\text {th }}, \mathrm{G} 4\right)$ group fed on diet supplemented with artichoke extract (whole plant) in a dose of $\mathbf{4 \%}$ and $\mathbf{8 \%}$ of the diet respectively; the fifth $\left(5^{\text {th }}, \mathrm{G} 5\right)$ and sixth $\left(6^{\text {th }}, \mathrm{G} 6\right)$ groups fed on basal diet supplemented with artichoke heads extract in a dose of $4 \%$ and $8 \%$ of the diet respectively; the seventh $\left(7^{\text {th }}, G\right.$ 7) and eighth $\left(8^{\text {th }}, G\right.$ 8) groups fed on basal diet supplemented with artichoke leaves extract in a dose of $4 \%$ and $8 \%$ of the diet respectively. Second group was scarified at the beginning (after being hyperlipidemic) to act as base line. At the end of the experimental period (6 weeks, 45 days after feeding the artichoke and its extract $)^{1}$, rats were fasted over night before sacrificing, blood was collected, centrifuged; serum was stored at $-20{ }^{\circ} \mathrm{C}$ until analysis.

\section{THE ANALYTICAL METHODS}

Total cholesterol, TC, (Bio Mérieux kits-Richmond 1973; and Allain et al., 1974), total triacylglycerol, TG, (Bicon kits- Bucolo \& David 1973), serum HDL (Bio Mérieux kits- Burstein et al., 1970, and Lopes Virella et al., 1977), serum LDL (Bio Mérieux kits- Friedewald $\boldsymbol{e t}$ al., 1972; Levy et al., 1981) contents were determined using suitable kits reagents. VLDL-C was determined by using the following equation: VLDL-C=total cholesterol - (HDL-C + LDL-C).

\section{STATISTICAL ANALYSIS}

Data are expressed as Mean \pm SE. Data were assessed by paired t-test (Avram

\footnotetext{
${ }^{1}$ The whole experiment since the adaptation, control diet lasted around three months.
}

1964; and Steel \& Torrie 1960). Anova and Tukey as post hoc analysis was done using SPSS version 11.

\section{Result:}

Data of table (I) reveal that group 2 (+ve control, hypercholesterolemic rats) had significantly higher cholesterol, LDL-C, VLDL-C and triacylglycerol levels than normal control, while HDL-C showed significantly lower levels. Data of table (I) also reveal that artichoke extract $(4,8 \%)$ significantly reduced cholesterol, LDL-C, VLDL-C and triacylglycerol concentration of $\mathrm{G} 3 \& 4$. The reduction of cholesterol, LDL-C, VLDL-C and triacylglycerol levels being more in G 4 than G3 with using higher extract concentration. Cholesterol reduction reaches $18.18 \%$ in $(\mathrm{G} 4)$, while LDL-C, VLDL-C and triacylglycerol reduction reach $26.03,13.23$ and $9.73 \%$ in G 4 respectively (table II). Data of table (I) reveal that artichoke head extract $(4,8 \%)$ significantly reduced cholesterol, LDL-C, VLDL-C and triacylglycerol concentration of $\mathrm{G} 5,6$ and the reduction being more in $\mathrm{G}$ 6 than G 5. Cholesterol, LDL-C, VLDL-C and triacylglycerol reduction reach 19.59, $23.72, \quad 32.28$ and $31.81 \%$ in $\mathrm{G} \quad 6$ respectively (table 2). Data of table (I) reveal that artichoke leaves extract $(4,8 \%)$ significantly reduced cholesterol, LDL-C, VLDL-C and triacylglycerol concentration of $G 7,8$. The reduction being more in $\mathrm{G} 8$ than G 7 with using higher extract concentration. Cholesterol, LDL-C, VLDL$\mathrm{C}$ and triacylglycerol reduction reach 22.18 , $28.69,29.09$ and $23.07 \%$ in G 8 respectively (table II). Leaves extract seems to be more powerful in reducing cholesterol and LDL-C concentration while head extract shows more reduction in VLDL-C and triacylglycerol concentration. The atherosclerotic indices (chol/HDL-C) are affected by the extract, especially by the leaves extract. The reduction reaches $26.16 \%$ with using higher extracts concentration.

\section{Discussion:}

Atherosclerosis is a complex multicellular process involving oxidation of cholesterol and the intracellular accumulation of oxidized cholesterol. This 

accumulation causes a cascade of inflammatory processes, resulting in an unstable atherosclerotic plaque that ultimately bursts, causing myocardial infarction. Botanical dietary supplements (herbs) can ameliorate this process and prevent cardiovascular disease at many steps in the process. Many herbs have antioxidant activity and can reduce lowdensity lipoprotein oxidation. Some phytosterols found in botanicals can inhibit cholesterol absorption.

The results of this study shows that aqueous organic extract of artichoke (whole plant, heads, and leaves) can significantly reduce cholesterol, LDL-C, VLDL-C, and triacylglycerol concentration of hypercholesterolemic rats and have no effect on HDL-C level. The results are in agreement with Pittler et al., 2002 (leaves extract lowers cholesterol levels); and Lupattelli et al., 2004 (cholesterol and HDL-C); and Englisch et al., 2000 (lowering cholesterol, LDL-C levels using artichoke dry extract).

There are several possible mechanisms that's through it artichoke extract can cause a significant effect on hypercholesterolemia. Artichoke extracts have been shown to produce various pharmacological effects, such as the inhibition of cholesterol biosynthesis and of LDL oxidation. Artichoke dietary supplementation seems to positively modulate hypercholesterolemia. These therapeutic properties may be attributed to mono- and di-caffeoylquinic acids and cynarin (one of the caffeoylquinic acid family) content of artichoke

(Speroni et al., 2003)

Artichoke contain at least 22 major compounds, 11 caffeoylquinic acids and 8 flavonoids as apigenin 7-O-glucuronide which is considered as the major flavonoid, 1,5-Di-O-caffeoylquinic acid which represent the major hydroxycinnamic acid, narirutin, and cynarin (Schutz et al., 2004).

Heckers et al. (1977) stated that cynarin in a dose of $250 \mathrm{mg}$ and $750 \mathrm{mg}$ daily, as treatment of familial Type IIa or Type IIb hyperlipoproteinaemia, has no hypolipidaemic effect since mean serum cholesterol and triglyceride concentrations were not significantly changed within 3 months. The oxygen functional groups at the 3- and 8-positions and exo-methylene moiety in alpha-methylene-gammabutyrolactone ring were found to be essential for the anti-hyperlipidemic activity of guaiane-type sesquiterpene. In addition, inhibition of gastric emptying was shown to be partly involved in anti-hyperlipidemic activity (Shimoda et al., 2003).

Aqueous organic artichoke leaf extract (ALE) increased the activity of the human endothelial nitric-oxide synthase (eNOS) promoter which produce nitric oxide that is considered as antiatherosclerotic principle in the vasculature thus could provide protection against cardiovascular diseases. Aqueous organic artichoke leaf extract increase the activity of eNOS mRNA expression and eNOS protein expression. The flavonoids luteolin and cynaroside increased eNOS promoter activity and eNOS mRNA expression. The increase in eNOS gene transcription may also contribute to ALE beneficial cardiovascular profile. Artichoke flavonoids are likely to represent the active ingredients mediating eNOS up-regulation ( $\mathbf{L i}$ et al., 2004). Li et al., 2004 found that cynarin acid did not increase eNOS mRNA

ALE also inhibited LDL oxidation expression.

(Brown and Rice-Evans, 1998) and reduced the production of intracellular reactive oxygen species by oxidized LDL in cultured endothelial cells and monocytes (Zapolska-Downar et al., 2002).

Artichoke leaves extract (ALE) inhibits the incorporation of ${ }^{14} \mathrm{C}$-labelled acetate into the non-saponifiable lipid fraction and thus reduces cholesterol biosynthesis at the level hydroxymethylglutaryl-CoA-reductase (HMG-CoA-reductase) through indirect modulation of HMG-CoA-reductase activity (Gebhardt 1995; Gebhardt 1996 a; and Gebhardt 1998). Furthermore, insulin stimulation of acetate incorporation was efficiently reduced by artichoke extracts. The reduction of HMGCoAreductase activity by the artichoke extracts might be responsible for the selective effect on acetate incorporation. Other studies suggested indirect inhibitory effects exerted at the level of HMG-CoA-reductase, a key enzyme in cholesterol biosynthesis (Fintlemann, 1996 a; Gebhardt, 1996 a; and Gebhardt, 1997). All of this might be 

due to some regulatory mechanism

of HMGCoA-reductase, which is influenced. This influence could possibly involve: 1) inhibition of activating mechanisms and/or 2) stimulation of inactivating mechanisms of the enzyme. Artichoke extracts effectively blocked insulin-dependent stimulation of HMGCoA-reductase without affecting insulin effects in general. Quantitative measurements show that artichoke extract inhibits cholesterol biosynthesis in a concentration dependent manner (ArtnerDworzak, 2000, Gebhardt, 1996 b). More recent findings indicate a role for the avonoid luteolin in inhibiting effects of cholesterol synthesis (Gebhardt, 1997). Because artichoke extracts may also enhance biliary cholesterol excretion as a result of the choleretic influence (Kirchhoff et al., 1994), both mechanisms (physiologically through indirect mechanism and enhance biliary cholesterol excretion) may contribute to the clinically known reduction of blood cholesterol levels (Gebhardt, 1996 b; and Gebhardt, 1998). Our results are in agreement with Bundy $\boldsymbol{e t}$ al. (2008).

Data of table (I) reveal that aqueous organic extract from artichoke (Cynara scolymus L.) plant, heads and leaves did not significantly affect HDL-C levels. They have no effect on HDL-C concentration despite the little increase. Head Extract cause 6.09 increase in HDL-C levels, which is higher than that caused by leaves extract $(5.91 \%)$.

Data of table (I) reveal that aqueous organic extract from artichoke leaves References:

1. Allain CC, Poor LS, Chan CSG, Richmond W, and Fu PC. (1974): Enzymatic determination of total serum cholesterol. Clin Chem .,20: 470-475.

2. Artner-Dworzak E, Mayr O, Mueller B, Maly K, and Grunicke H. (2000): Influence of the artichoke extract on lipid metabolism. Phytomedicine; Supplement (II): 46 SL-91.

3. Avram G. (1964):"Quantitative Data." In: Biostatistics: An Introductory text. Chapter 2, page $53 \& 63$. The MacMillan Company, New York, Collier MacMillan limited, London.

4. Bhattaram VA, Graefe U, Kohlert C, Veit $M$, and Derendorf H. (2002): Pharmacokinetics and bioavailability of
(Cynara scolymus L.) significantly reduced triacylglycerol levels due to presence of certain compounds in the artichoke as sesquiterpenes (cynaropicrin, aguerin B, and grosheimin) and sesquiterpene glycosides (cynarascolosides A, B, and C) (Shimoda et al., 2003) and also the presence of oxygen functional groups at the 3- and 8-positions and exo-methylene moiety in alpha-methylene-gammabutyrolactone ring are essential for the antihyperlipidemic activity of guaiane-type sesquiterpene. Our results for triacylglycerol are in agreement with (Shimoda et al., 2003) and are in disagreement with (Lupattelli et al., 2004). The traditional use of a plant-based remedy implies relative safety, for artichoke. Held, 1992, Fintelmann, 1996 b; 1997; 1999 reported the absence of serious adverse events which means that ALE is relatively well tolerated but Ernest et al., 2001; and Pittler et al., 2002 stated that these limited evidence, which is available is not sufficient to recommend ALE as a treatment option for hypercholesterolaemia.

\section{CONCLUSION:}

This prospective study could contribute evidence beside the other published ones to recommend artichoke extract for aiding in treating hyperlipoproteinemia since artichoke extract seems to positively modulate hypercholesterolemia.

herbal medicinal products. Phytomedicine; 9 (3): 1-33.

5. Brown JE, and Rice-Evans CA. (1998): Luteolin-rich artichoke extract protects low density lipoprotein from oxidation in vitro. Free Radic Res.; 29:247-255.

6. Bucolo G, and David H. (1973): Quantitative determination of triglycerides by the use of enzymes. Clin chem.; 19: 476482.

7. Bundy R, Walker AF, Middleton RW, Wallis C, and Simpson HC. (2008): Artichoke leaf extract (Cynara scolymus) reduces plasma cholesterol in otherwise healthy hypercholesterolemic adults: a randomized, double blind placebo controlled 
trial. Phytomedicine; 15 (9): 668-675.

8. Burstein M, Scholnick HR. and Monfin R. (1970): Rapid method for the isolation of lipoproteins from human serum by precipitation with polyanions. J. Lipid Res; 11: $585-595$

9. Cervellati, R, Benzulli, C, Guerra, MC, and Speroni, E. (2002): Evaluation of antioxidant activity of some natural polyphenolic compounds using the BriggsRauscher. J Agri.Food Chem.; 50: 75047509.

10. Englisch W, Beckers C, Unkauf M, Ruepp $\mathrm{M}$, and Zinserling V. (2000): Efficacy of Artichoke dry extract in patients with hyperlipoproteinemia.

Arzneimittelforschung.; 50: 260-265.

11. Expert Panel (2002): Third Report of the National Cholesterol Education Program (NCEP) Expert Panel on Detection, Evaluation, and Treatment of High Blood Cholesterol in Adults (Adult Treatment Panel III) final report. National Cholesterol Education Program (NCEP) Expert Panel on Education, Evaluation, and treatment of high blood cholesterol in adults (Adult treatment Panel III). Circulation; 106 (25): 3140-3421

12. Ernst E, Pittler MH, Stevinson C, White A, and Eisenberg D. (2001): The desktop guide to complementary and alternative medicine. Edinburgh: Mosby.

13. Fintelmann V. (1996 a): Therapeutic role and mechanism of action of artichoke leaf extract: hypolipemic, antioxidant, hepatoprotective and choleretic properties. Phytomed.; Supplement (I): 50.

14. Fintelmann V. (1996 b): Antidyspeptische und lipidsenkende Wirkung von Artischockenextrakt. Z Allg Med.; 72: 4857.

15. Fintelmann V, and Wegener T. (1997): Langzeitanwendung von Artischockenblaetterextrakt (Hepar SL forte) bei dyspeptischem Symptomkomplex. Phytotherapiekongress Wuerzburg 27-28 November.

16. Fintelmann V. (1999): Artischockenextrakt bei dyspeptischem Symptomenkomplex. Methodik und Ergebnisse einer Anwendungsbeobachtung. Zeitschrift fuer Phytotherapie; 20: 93-95.

17. Friedewald WT, Levy RI, and Fredrickson DS. (1972): Estimation of the concentration of low-Density lipoprotein cholesterol in plasma without use of the preparative ultra centrifuge. Clin Chem.; 18: 499-502.

18. Gebhardt R. (1995): Artischockenextrakt-in vitro Nachweis einer Hemmwirkung auf die Cholesterinbiosynthese. MedWelt.; 46: 348350 .
19. Gebhardt R. (1996 a): Neue Erkenntnisse zur Wirkung von Artischockenblaetterextrakt. Z Allg Med.; 72:20-23.

20. Gebhardt R. (1996 b): Hepatocellular actions of artichoke extracts: stimulation of biliary secretion, inhibition of cholesterol biosynthesis and antioxidant properties. Phytomed.; Supplement (I): 51.

21. Gebhardt R. (1997): Inhibition of hepatic cholesterol biosynthesis by artichoke leaf extracts is mainly due to luteolin. Cell Bio Toxicol.; 13: 58.

22. Gebhardt R. (1998): Inhibition of cholesterol biosynthesis in primary cultured rat hepatocytes by artichoke (Cynara scolymus L.) extracts. J Pharmacol Exp Ther.; 286 (3): 1122-1128.

23. Heber D. (2001): Herbs and atherosclerosis. Cur Atheroscler Rep.; 3 (1): 93-96.

24. Heckers H, Dittmar K, Schmahl FW, and Huth K. (1977): Inefficiency of cynarin as therapeutic regimen in familial type II hyperlipoproteinaemia. Atherosclerosis; 26(2): 249-253.

25. Held C. (1992): Von der deutschungarischen Phytopharmakakonferenz. Budapest 20. Z Klin Med.; 47:92.

26. Holme I. (1990): An Analysis of randomized trials evaluating the effect of cholesterol reduction on total mortality and coronary heart disease incidence. Circulation; 84 (6): 2610-2611.

27. Jimenez-Escrig A, Dragsted LO, Daneshvar B, Pulido R, and Saura-Calixto F. (2003): In vitro antioxidant activities of edible artichoke (Cynara scolymus L.) and effect on biomarkers of antioxidants in rats. J Agri. Food Chem.; 51(18): 5540-5545.

28. Kirchhoff R, Beckers CH, Kirchhoff GM, et al. (1994): Increase in choleresis by means of artichoke extract. Results of a randomised placebo-controlled double-blind study. Phytomedicine; 1:107-115.

29. Levy RI. (1981): Cholesterol lipoprotein, apolipoproteins, and heart disease: Present status and future properties. Clin Chem.; 27: 653-662.

30. Li H, Xia N, Brausch I, Yao Y, and Forstermann U. (2004): Flavonoids from artichoke (Cynara scolymus L.) up-regulate endothelial-type nitric-oxide synthase gene expression in human endothelial cells. $\mathbf{J}$ Pharmacol Exp Ther.; 310: 926-932.

31. Lopes-Virella MF, stone PG, Ellis S, and Coldwell JA. (1977): Cholesterol determination in high density lipoprotein separated by three different methods. Clin Chem.; 23: 882-884.

32. Lupattelli G, Marchesi S, Lombardini R, et al. (2004): "Artichoke juice improves 
33. endothelial function in hyperlipemia. Life Sci.; 76 (7): 775-782.

34. National Research Council (NRC) Committee on Animal Nutrition, (1978): Nutrient Requirement of Laboratory animals. No. 10. $3^{\text {rd }}$ Revised Edition. National academy of science, National Research Council, Washington, D. C.

35. Pittler $\mathrm{MH}$, Thompson $\mathrm{CJ}$, and Ernst E. (2002): Artichoke leaf extract for treating hypercholesterolaemia. The Cohrane Database Systematic Rev.; (3): CD 003335. DOI: $10.1002 / 14651858$.

36. Pyörälä K, De Backer G, Graham I, PooleWilson P, and Wood D. (1994 a): Prevention of coronary heart disease in clinical practice: recommendations of the task force of the European Society of Cardiology, European Atherosclerosis Society and European Society of hypertension. Atherosclerosis; 110 (2): 121161.

37. Pyörälä K, De Backer G, Graham I, PooleWilson P, and Wood D. (1994 b): Prevention of coronary heart disease in clinical practice: recommendations of the task force of the European Society of Cardiology, European Atherosclerosis Society and European Society of hypertension. Eur Heart J.; 110 (2): 13001331.

38. Reeves PG, Nielson FH, and Fahey GC, Jr. (1993): Ain 93 Purified diets for laboratory rodents: Final report of the American Institute of Nutrition and HOC Wriling Committee on the Reformation of the Ain 76 A Rodent Diet. J Nut.; 123: 1939-1952.

39. Richmond W. (1973): Preparation and properties of cholesterol oxidase from Nocardia Sp. And its application to the enzymatic assay of total cholesterol in serum. Clin Chem.; 19: 1350-1356.
40. Schütz K, Kammerer D, Carle R, and Schieber A. (2004): Identification and quantification of caffeoylquinic acids and flavonoids from artichoke (Cynara scolymus L.) heads, juice, and pomace by HPLCDAD-ESI/MS(n). J Agri Food Chem.; 52 (13): 4090-4096

41. Shimoda $\mathrm{H}$, Ninomiya $\mathrm{K}$, Nishida $\mathrm{N}$, et al. (2003): Anti-hyperlipidemic sesquiterpenes and new sesquiterpene glycosides from the leaves of artichoke (Cynara scolymus L.): structure requirement and mode of action. Bioorg Med Chem Lett.; 13 (2): 223-228.

42. Speroni E, Cervellati R, Govoni $\mathrm{P}$, et al. (2003): Efficacy of different Cynara scolymus preparations on liver complaints. $\mathbf{J}$ Ethnopharmacol.; 86: 203-211.

43. Steel RG, and Torrie JH. (1960):"Principles and procedures of statistics." McGraw Hill, Book company, Inc., New York.

44. Taylor, L. (2002): Herbal secrets of the rainforest, 2 nd Ed. Published and copyrighted by Sage press, Inc.

45. Wagner H M, Steppat R, and Altenkirch H. (1984): Animal experiments on the neurotoxicity of organic solvents on rats prechallenged with heavy metals. Schriftenr Ver Wasser Boden Lufthyg; 59:191-200.

46. Wang M, Simon J, Aviles I, et al. (2003): Analysis of antioxidative phenolic compounds in artichoke. J Agri Food Chem.; 51(3): 601-608.

47. Wegener T. (2002): The status of herbal antilipemic agents. Wien Med Wochenscher; 152(15-16): 412- 417.

48. Zapolska-Downar D, Zapolski-Downar A, Naruszewicz M, et al. (2002): Protective properties of artichoke (Cynara scolymus) against oxidative stress induced in cultured endothelial cells and monocytes. Life Sci.; 71:2897-2908.

Table (I): Lipid profile of rats fed on extracts of artichoke (whole plant, head, and leaves).

\begin{tabular}{|c|c|c|c|c|c|c|c|}
\hline & & $\begin{array}{c}\text { Cholesterol } \\
\text { mg/dl }\end{array}$ & $\begin{array}{c}\text { HDL-C } \\
\text { mg/dl }\end{array}$ & $\begin{array}{c}\text { LDL-C } \\
\text { mg/dl }\end{array}$ & $\begin{array}{l}\text { VLDL-C } \\
\text { mg/dl }\end{array}$ & $\begin{array}{c}\text { Triacylglycerol } \\
\text { mg/dl }\end{array}$ & $\frac{\text { Chol }}{\text { HDL-C }}$ \\
\hline \multirow[t]{2}{*}{ G 1} & \multirow{2}{*}{$\begin{array}{c}\text { M } \\
\pm \text { SE }\end{array}$} & 92.15 & 42.31 & 35.03 & 14.81 & 80.28 & 2.18 \\
\hline & & 1.95 & 0.85 & 1.04 & 0.35 & 0.94 & 0.01 \\
\hline \multirow[t]{2}{*}{ G 2} & \multirow{2}{*}{$\begin{array}{c}\text { M } \\
\pm \text { SE }\end{array}$} & $183.85^{1,3-8 *}$ & $35.28^{1^{*}}$ & $114.40^{1,3-8^{*}}$ & $34.17^{1,6,8 *}$ & $179.27^{1,6,8 *}$ & $5.24^{1,3-8^{*}}$ \\
\hline & & 1.93 & 0.90 & 1.86 & 0.75 & 4.39 & 0.12 \\
\hline \multirow[t]{2}{*}{ G 3} & \multirow{2}{*}{$\begin{array}{c}\text { M } \\
\pm \mathrm{SE} \\
\end{array}$} & $164.71^{1,2,4,6,8 *}$ & $36.12^{1^{*}}$ & $97.05^{1,2,4,6,8^{*}}$ & $31.54^{1,2,6,8}$ * & $169.43^{1,2,6,8 *}$ & $4.59^{1,2,4,6,8^{*}}$ \\
\hline & & 1.77 & 1.10 & 1.09 & 0.99 & 2.54 & 0.11 \\
\hline \multirow[t]{2}{*}{ G 4} & \multirow{2}{*}{$\begin{array}{c}\text { M } \\
\pm \text { SE } \\
\end{array}$} & $150.42^{1,2,3,5,6,7,8^{*}}$ & $36.15^{1^{*}}$ & $84.62^{1,2,3,5,7^{*}}$ & $29.65^{1,2,6,8}$ * & $161.82^{1,2,6,8^{*}}$ & $4.17^{1,2,3,5,6,7^{*}}$ \\
\hline & & 2.25 & 0.67 & 1.28 & 1.51 & 6.22 & 0.09 \\
\hline G 5 & $\mathbf{M}$ & $166.61^{1,2,4,6,8^{*}}$ & $36.06^{1 *}$ & $98.37^{1,2,4,6,8^{*}}$ & $32.18^{1,6,8^{*}}$ & $171.99^{1,6,8}$ * & $4.70^{1,2,4,6,8^{*}}$ \\
\hline
\end{tabular}


Effect of Cynara .....

\begin{tabular}{|c|c|c|c|c|c|c|c|}
\hline & $\pm \mathrm{SE}$ & 2.88 & 1.77 & 1.42 & 1.21 & 5.70 & 0.19 \\
\hline \multirow[t]{2}{*}{ G 6} & \multirow{2}{*}{$\begin{array}{c}\mathrm{M} \\
\pm \mathrm{SE}\end{array}$} & $143.07^{1,2,3,4,5,77^{*}}$ & $37.26^{1^{*}}$ & $\mathbf{8 1 . 5 8}^{1,2,3,3,7,78^{*}}$ & $\mathbf{2 4 . 2 3}^{1,2,3,3,4,5,7 *}$ & $137.92^{1,2,3,4,5,7,8^{*}}$ & $3.87^{1,2,3,4,5,7^{*}}$ \\
\hline & & 2.49 & 1.22 & 1.21 & 1.23 & 6.21 & 0.11 \\
\hline \multirow[t]{2}{*}{ G 7} & \multirow{2}{*}{$\begin{array}{c}\mathrm{M} \\
\pm \mathrm{SE} \\
\end{array}$} & $163.22^{1,2,4,6,8 *}$ & $35.98^{1^{*}}$ & $96.63^{1,2,4,6,8 *}$ & $30.61^{1,2,6,8 *}$ & $160.71^{1,2,6,8 \text { * }}$ & $4.57^{1,2,4,6,8^{*}}$ \\
\hline & & 2.70 & 1.28 & 0.99 & 1.40 & 6.42 & 0.11 \\
\hline \multirow[t]{2}{*}{ G 8} & \multirow{2}{*}{$\begin{array}{c}\mathrm{M} \\
\pm \mathrm{SE}\end{array}$} & $147.84^{1,2,3,5,7 \text { * }}$ & $37.43^{1,2 *}$ & $87.27^{1,2,3,5,6,6,7}$ * & $23.14^{1,2,3,4,4,5,7 *}$ & $122.25^{1,2,3,4,5,6,6,7}$ & $3.96^{1,2,3,5,7 *}$ \\
\hline & & 1.49 & 0.69 & 1.54 & 0.60 & 1.95 & 0.06 \\
\hline \multirow[t]{3}{*}{ One } & \multicolumn{7}{|c|}{ Way ANOVA } \\
\hline & $\mathbf{F}$ & $149.536 *$ & 4.001* & 305.878* & 35.564* & 48.62* & 68.944* \\
\hline & $\mathbf{P}<$ & \begin{tabular}{|l|l|}
0.000 \\
\end{tabular} & 0.001 & 0.000 & 0.000 & 0.000 & 0.000 \\
\hline
\end{tabular}

Table (II): Percent (\%) change of the tested groups from their respective controls

\begin{tabular}{|c|c|c|c|c|c|c|c|}
\hline & & Cholesterol & HDL-C & LDL-C & VLDL-C & TG & $\frac{\text { Chol }}{\text { HDL-C }}$ \\
\hline \multirow[t]{2}{*}{ G 3} & $\mathrm{a}$ & 78.74 & -14.63 & 177.05 & 112.96 & 111.05 & 110.70 \\
\hline & $\mathrm{b}$ & -10.41 & 2.38 & -15.17 & $\begin{array}{l}-7.70 \\
\end{array}$ & $\begin{array}{l}-5.49 \\
\end{array}$ & -12.35 \\
\hline \multirow[t]{2}{*}{ G 4} & $\mathrm{a}$ & 63.23 & -14.56 & 141.56 & 100.20 & 101.57 & 91.58 \\
\hline & $\mathrm{b}$ & -18.18 & 2.47 & -26.03 & -13.23 & $\begin{array}{l}-9.73 \\
\end{array}$ & -20.30 \\
\hline \multirow[t]{2}{*}{ G 5} & $\mathrm{a}$ & 80.80 & -14.77 & 180.81 & 117.29 & 114.24 & 115.71 \\
\hline & $\mathrm{b}$ & $\begin{array}{l}-9.38 \\
\end{array}$ & 2.21 & -14.01 & -5.82 & -4.06 & -10.26 \\
\hline \multirow{2}{*}{ G 6} & & 6043 & 1153 & 14011 & 5625 & 5220 & 8176 \\
\hline & $\mathrm{b}$ & -19.59 & 6.09 & -23.72 & -32.28 & -31.81 & -24.38 \\
\hline \multirow{2}{*}{ G 7} & $\mathrm{a}$ & 77.12 & -14.96 & 175.85 & 106.68 & 100.19 & 109.73 \\
\hline & $\mathrm{b}$ & -11.22 & 1.98 & -15.53 & -10.42 & -10.35 & -12.75 \\
\hline \multirow{2}{*}{ G 8} & a & .26 & -11.94 & 89 & 63.61 & 71.80 & 7750 \\
\hline & $\mathrm{b}$ & -22.18 & 5.61 & -28.69 & -29.09 & -23.07 & -26.16 \\
\hline
\end{tabular}


تأثير مستخلص الخرشوف على صورة الليبيدات في الفئران المصابة بارتفاع الليبيدات

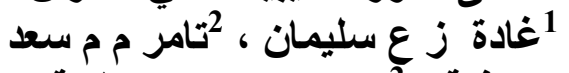

1": المعهد القومي للتغذية ، 2: وحدة الابحاث الطبية، هيئة الطاقة الذرية

الملخص

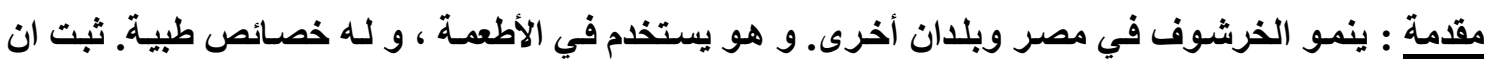

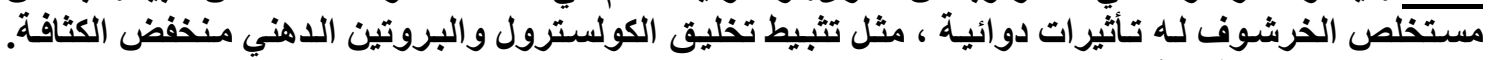

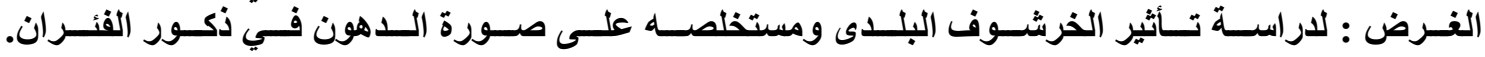

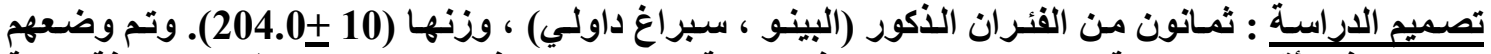

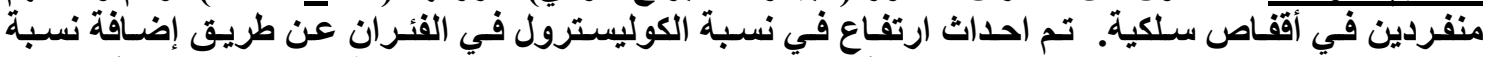

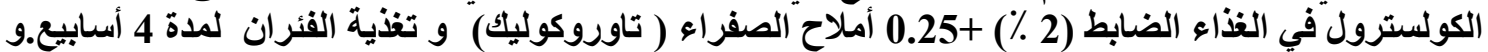

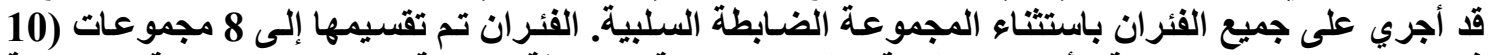

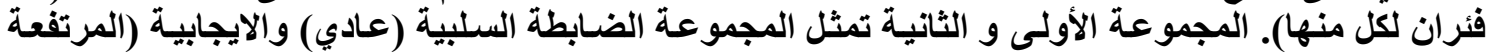

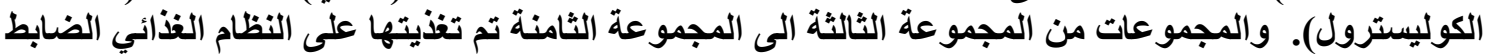

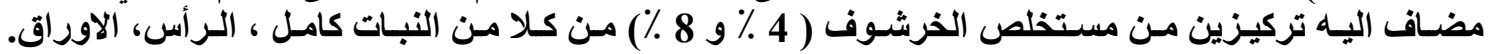

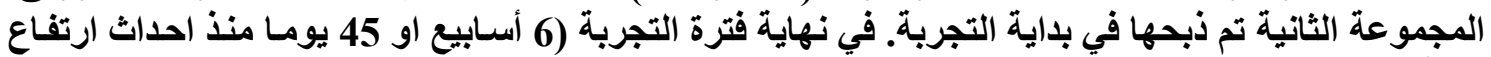

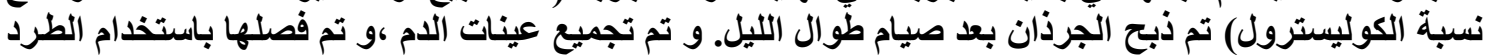

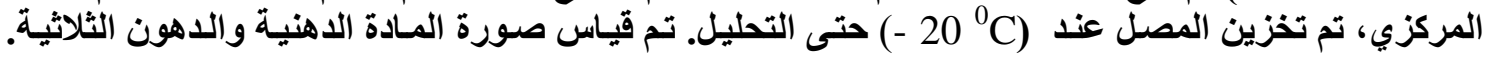

مناقشة النتائج : مستخلصات الخرشوف (النبات كاملا ، والرأس ، الاوراق) قد ادت الى الى انخفاض كبير معنوي

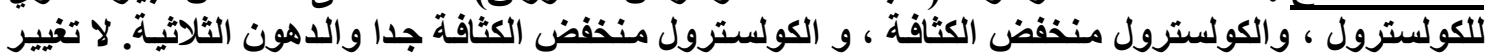

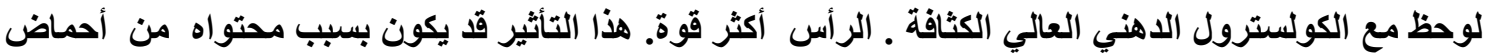

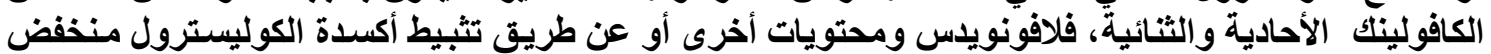
الكثافة.

الاستتناج : يبدو ان اضافة مستخلص الخرشوف يبدو إيجابيا في التأثير على ارتفاع الكوليسترول و كنلك يمكن

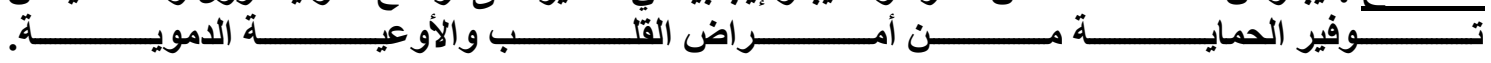

الكلمات الرئيسية : الخرشوف ، تصلب الثرايين ،المواد المضادة للأكسدة ، صورة الدهون. 